\title{
СОМАТСКИ ФРАЗЕМИ СА КОМПОНЕНТОМ ВLOD/КРВ У НОРВЕШКОМ И СРПСКОМ ЈЕЗИКУ
}

\begin{abstract}
Предмет истраживања представља међујезичко поређење соматских фразема са компонентом blod/крв у норвешкој и српској фразеологији са когнитивног становишта. Основни циљ овог рада је да се применом две методе, контрастивне и концептуалне анализе, укаже на сличности, разлике и специфичности, тј. установи степен семантичке симетрије посматраних фразеологизама у наведеним језицима. Одређивањем начина мотивације и класификацијом фразеологизама у одговарајућа позитивна и негативна семантичка поља на основу емоције коју денотирају, истраживањем су установљена три типа еквиваленције као и изуетно развијена симболика и полисемија лексема нор. blod / срп. крв у контрастираним језицима. Корпус је ексцерпиран из одговарајућих једнојезичних и двојезичних речника наведених језика.
\end{abstract}

Кључне речи: соматизам, фразеологизам, blod, крв, норвешки, српски

\section{1. Увод}

Соматски фразеологизми дефинишу се као вишелексемски спојеви стабилне структуре и значења и релативно устаљеног лексичког састава, идиоматичне конструкције, код којих је једна од компоненти назив за део људског тела, органа а по некима и телесне течности и углавном означавају човекове психичке и физичке особине (Мршевић-Радовић 1987:30). Делови тела чине једно од најважнијих и најстаријих семантичких поља у свим језицима, они представљају фразеолошку и језичку универзалију, и због таквог универзалног карактера проучавање соматизама је незаобилазно у специфичној анализи фразеолошких јединица било ког језика (Тривић према Чермак, 2015:4). Тако у многим језицима, телесно искуство постаје универзалан извор за концептуализацију људске стварности односно формирање језичке слике света. Важна улога делова и изгледа тела *_ jovana.vurdelja@gmail.com 
или функције које обавља се може објаснити историјским развојем људске цивилизације - делови тела су већ имали своје називе у тренутку када је требало обележити нове концепте, због чега сасвим очекивано, постају изворни домен у тим процесима (Штрбац према Kraska-Szlenk, 2017:85).

Фразеолошке јединице са компонентом blod/крв припадају унутрашњој соматској фразеологији заједно са другим телесним течностима (нпр. слуз, зној, сузе), односно другим унутрашњим органима (нпр. стомак, желудац, бубрези), док спољашњој соматској фразеологији припадају сви видљиви делови човековог тела (нпр. глава, лице, очи, уши, руке, ноге, прсти). Поред различитих ритуалних и магијских функција и представе о крви као пребивалишту душе, ова лексема неизоставан је саставни део фразеолошког фонда готово сваког језика било у виду конституента фразеологизама, било као коренска основа вербала који улази у састав неке фразеолошке јединице (Сивачки, Мутавџић, 2016:57). У већини језика семантичка распрострањеност ове лексеме у оквиру фразеологизама двоструко је мотивисана:

a) с једне стране, делови тела чине окосницу фразеолошког фонда једног језика, будући да се у оквиру поимања света који га окружује, човек полази од онога што му је најпознатије, а то је сопствено тело;

б) с друге стране, симболика саме крви, доводи до појаве лексеме $b l o d / \kappa p в$ у најразличитијим семантичким пољима, и означава како позитивне, тако и негативне емоције (Сивачки, 2017:385).

Предмет овог истраживања представља међујезичко поређење одређеног сегмента фразеолошких система норвешког и српског језика са циљем утврђивања њихових универзалности и специфичности. Конкретније, у раду се врши контрастивна анализа соматских фразема са компонентом blod/крв са когнитивног становишта, при чему је норвешки изворни, а српски циљни језик. Термин контрастивна анализа преузет је из контрастивне лингвистике, чији предмет проучавања представља уочавање сличности и разлика између два или више језика, а њени резултати имају широку примену у настави страних језика и у превођењу, али и општој лингвистици, јер испитује језичке типове и језичке универзалије (Тривић према Станковић 2015:14). 
Методом концептуалне анализе биће утврђен начин мотивације фразеологизама путем откривања концептуалних механизама који се налазе у њиховој основи. Постулирањем појмовних метафора, одређивањем метонимија или уочавањем симболичних представа, соматски фраземи биће сврстани у одговарајућа семантичка поља, позитивна или негативна, зависно од емоције коју означавају на основу чега ће се утврдити степен семантичке симетрије односно асиметрије.

Концептуализација емоција остварује се путем когнитивних механизама, концептуалне метафоре и метонимије које су у основи концептуалне анализе спроведене у раду у оквирима које су поставили Џ. Лејкоф, М. Џонсон и 3. Кевечеш. Метафора подразумева пресликавање структуре једног појма или појмовног домена на други појам или појмовни домен, односно са изворног на циљни домен, при чему су изворни домени најчешће конкретни, људско тело, здравље и болест, животиње, биљке а циљни домени углавном апстрактни и неопипљиви појмови (Klikovac, 2004:17-19), па се појмовне метафоре посматрају као „,разумевање једног појма или појмовног домена уз помоћ другог“ (Lakeoff 1993:206-207). Поред метафоре, значајан је и појмовно-значењски механизам метонимије која има референцијалну функцију, односно омогућава да један ентитет представља други (Lakeoff and Johnson, 2003:36).

У наведеном теоријско-методолошком оквиру, хипотеза на којој се ово истраживање заснива утемељена је на претпоставци да су соматске компоненте око којих се формирају одговарајући фразеологизми иманентни говорницима различитих језика и припадају групи универзалија па је самим тим очекиван висок степен подударности између полазних и циљних израза у контрастираним језицима. Такође, очекује се да ће бити потврђена не само универзалност, већ и антропоцентричност/антропомеричност соматске фразеологије у анализираним фразеолошким фондовима.

\section{2. Концептуална анализа}

\section{1 Симболика крви}

Кроз историју човечанства, у свим временима и народима, забележене представе о крви осцилирале су у семантичком опсегу од 
еликсира живота до симбола смрти, међутим упркос тим парадоксално различитим интерпретацијама, њена фундаментална улога и значај евидентна је у готово свим културама и цивилизацијама без обзира на дуално поимање као објекат страха или обожавања. Наиме, иако су особине крви дуго остале непознате и неразјашњене, чињеница коју су људи врло рано схватили је да док у организму тече крв - у њему тече живот. Дакле, одраз таквог схватања, да је крв носилац односно обележје живота, налазимо код бројних народа у свету, при чему сачувана народна веровања у оквиру обредно-обичајних пракси односно религијским представама, сведоче да је „крв нешто од чега непосредно зависи сам живот“, јер при губитку крви губи се снага, дух а самим тим и живот (Ивановић Баришић, 2016). На том темељу, у народним представама, крв је перцепирана универзално као исходиште и симбол живота, супстанца животне снаге, место пребивалишта душе, има разноврсне ритуално-магијске функције, пре свега оне продуктивне природе (Словенска митологија, 2001:158), и као таква игра круцијалну улогу у концептуализацији не само човекових осећања и међусобних релација, већ и целокупног света који га окружује.

Из дијахронијске перспективе, бројна веровања и обичаји доводе се у корелацију са крвљу и забележени су код готово свих заједница прединдустријског времена у развоју цивилизација. Наиме, крв има развијену симболику у свим културама, а парадигма крви интерферира са вишезначним симболичким садржајем манифестованом још при артикулисању различитих митско-магијских представа при чему крв представља животну силу и животни принцип, душу, виталност, има регенеративу моћ и енергију.Тако се поимање крви као симбола силе подмлађивања, живота, снаге и жртве у крви рефлектује у примерима још из средњег века кад су за време лова на вештице, џелати смели да тргују људском крвљу, у веровању да враћа снагу и смирује демоне. Крв као извор првобитног живота налазимо у исламској традицији, на шта упућује чињеница да је према Курану Алах створен од угрушка крви. Са друге стране, на темељу библијске митологије, прво убиство, Авеља од стране брате Каина представља крв као седиште животне снаге и духа. Есенцијална улога крви рефлектује се и у гледишту Хипократа, оца медицине, који је сматрао да човек одржава живот путем крви, пљувачке, жуте и црне жучи, а да се на основу тога која 
од текућина преовладава, разликују четири типа људи. О значају крви и њеној функцији сведоче и експерименти алхемичара у 16. и 17. веку који су се спроводили са циљем утврђивања свих њених тајни с обзиром да је имала статус праве материје филозофске основе мудраца.

По аналогији са бојом, у народу су употребљавани предмети или материје који се могу сматрати њеним супститутима, а најпознатији је црвена боја, а у том смислу крв се изједначава с ватром, топлотом или самом суштином живота, док се на основу агрегатног стања доводи у корелацију с различитим географским елементима као што су реке или други водени токови, чиме јој се аналогно приписују и њихове особине (Ивановић Баришић, 2016).

Осим у духовној, топос крви употребљаван је и у социјалној сфери, у случајевима када се настојао нагласити осећај припадности и повезаности појединца са заједницом, родом па и народом, што се најбоље манифестује у изреци заједничкој за готове све народе - да крв није вода, односно норвешки blod er tykere enn vann.

\section{2 Семантички опсег лексема blod у норвешком и крв у српском језику}

Лексеме нор. blod / срп. крв налазе се у склопу основног лексичког фонда контрастираних језика, а увидом у доступне једнојезичне речнике, утврђено је да се велики број значења, како основних тако и секундарних и фигуративних подудара у анализираним језицима: а) црвена текућина, течност која тече кроз крвне жиле, судове човечјег и животињског организма, храни га и врши измену твари, материје у њему; б) сродство/порекло/лоза; в) ћуд/карактер/темперамент; г) живот/животна снага; д) крвопролиће/убиство; ђ)крвна освета.

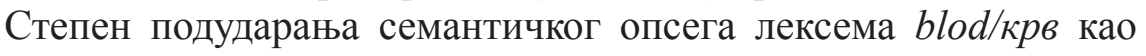
компоненте соматских фразеологизама у контрастираним језицима забележен је у случајевима када је фразем настао на семантичком талогу у оквиру којег лексема фигурира у прототипском значењу, али и када је извршена десемантизација услед фразеолошког окружења, као и у оквиру израза негативне и позитивне конотације. (Не)подурање концептуализације односно начин лексикализације фразеологизама у поменутим језицима са лексемом blod/крв биће анализиран у оквиру негативних и позитивних семантичких поља. 


\section{3 Семантичка поља и постулирање појмовних метафора}

Класификација фразеолошких јединица са компонентом blod/ крв биће извршена путем сврставања у одговарајућа семантичка поља, позитивно и негативно, а у оквиру наведених категорија биће утврђени начини њихове мотивације (метафорички, метонимијски, симболички). Концептуална анализа фразеологизама ће бити спроведена унутар следећих семантичких поља:

- Позитивна семантичка поља: љубав/наклоност, блискост

- Негативна семантичка поља: љутња/бес/гнев, мржња, хладнокрвност, страх, стид, разочарење, туга/патња, кривица

\section{4 Позитивна семантичка поља}

У оквиру ове категорије, фразеолошке јединице са компонентом blod/крв биће контрастивно анализиране у случајевима када је изражена маркираност у виду позитивне емоције којом се денотира осећање љубав/наклоност и блискост.

\section{Семантичко поље ЉУБАВ/НАКЛОНОСТ}

Фразеолошка јединица норвешког језика å ha i blodet/å ligge (noen) i blodet у значењу 'høre til ens vesen; voere helt naturlig for noen iscer gjennom fysisk arv' (бити део нечијег бивства, потпуно природно припадати, посебно у случају физичког наследства) има свој фразеолошки еквивалент у српском језику битиллежай у крви некоме и означава особу којој је нешто у крви, блиско и драго, односно како Матешић наводи за српски фразеолошки еквивалент, 'бити прирођено/урођено/од рођења у нарави ${ }^{\circ}$. Контрастивном анализом је установљена подударност на лексичком и структурном нивоу, будући да су у контрастираним језицима уочене идентичне лексичке варијабле у погледу глаголских компоненти бийи и лежайи у крви. Фразеологизми су настали метафоризацијом, при чему је постулирана појмовна метафора ЉУБАВ/НАКЛОНОСТ ЈЕ ТЕЧНОСТ. Имајући у виду идентичну мотивациону слику, на семантичком нивоу је забележена апсолутна еквиваленција. У српском језику, поменути фразеологизми јављају се и у значењу осећайи наклоносй/симйайије ирема некоме (срп. ти си ми у крви) за које нису утврђени фразеолошки екви- 
валенти у норвешком, па је установљен однос нулте еквиваленције. Фразеологизам је настао метафоризацијом при чему се дата емоција концептуализује као течност, па фразеологизам почива на метафори ЉУБАВ ЈЕ ТЕЧНОСТ.

У оквиру истог семантичког поља фигурира и фразеолошки пар нор. å gå noen $i$ blodet у значењy 'bli en del av noens personlighet, natur (постати део нечије личности/природе) и срп. ући у крв и означава прећи у крв, ући (улазити) у навику, постајати навика, потреба. Српски фразеологизам лексикализује и значење постати драг/мио некоме, заокупити некога. Фразеологизми су настали метафоризацијом. Блискост/љубав се концептуализује као течност, а појмовна метафора формулисана у позадини фразеологизма је ЉУБАВ ЈЕ ТЕЧНОСТ. Контрастивном и концептуалном анализом је установљен однос апсолутне еквиваленције.

Осећање љубави/наклоности у полазном језику концептуализује се и путем фразема å utgyte blod/utøse blod у значењу 'såre(s) slik at blodet flyter, stå for blodig og massiv dreping av mennesker (ранити тако да се пролива крв, крваво и масовно убиство људи) и упућује на особу која пролива своју крв и спремна је на жртву због некога у знак љубави. Исто значење у циљном језику транспонује се путем фразема gайи своје крви некоме/gaйu за коїа заgюу кай крви. Поменути фразеологизми почивају на перцепцији крви као есенцијалне течности за сва жива бића и симболички су мотивисани (Сивачки, 2017:387), а настали су перифразом базне синтагме (Ристић према Мушовић, 2013:118). Перифраза је семантичка фигура која настаје на бази лексичко-семантичког функционисања речи: један појам се замењује његовим вишечланим описом, с циљем да се оживи слика која је мотивисала фразеологизам (Ристић према Мршевић-Радовић, 2013:118). Контрастивном анализом је констатован однос парцијалне еквиваленције услед разлика на лексичком и структурном нивоу (глаголске варијабле/лексичка допуна - кап крви).

Концепт жртве зарад љубави у норвешком језику вербализује се и путем фразема å ofre liv/blod у значењу 'ofre, våge liv eller helse' (жртвовати живот или здравље) и денотира особу која као доказ љубави и наклоности жртвује свој живот. У српском језику исто значење транспонује се путем претходно наведених фразема gай своје крви 
некоме/gaйи за коїа заgњу кай крви или фраземом без компоненте

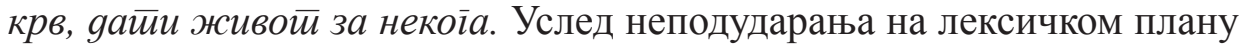
(различитих глаголских компоненти) установљен је однос парцијалне еквиваленције. Концептуалном анализом констатована је симболичка мотивисаност фразема као и потпуна семантичка подударност.

\section{Семантичко поље БЛИСКОСТ}

Циљни домен блискост у норвешком језику лексикализује фразеологизам blod er (aldri så tynt at det ikke er) tykkere enn vann (крв никада није толико ретка да не би могла бити гушћа од воде) у значењу 'selv det fjerneste slektskap gir (forpliktende) tilknytning; slektsfølelsen gjør seg gjeldende'. Његов фразеолошки еквивалент у српском језику представља фразем крв није воgа и денотира значај родбинске везе и колико је важно јесмо ли или нисмо са неким у роду (Милорадовић, 2016:11). Фразеологизмом крв није воgа означава се да су некаква склоност или својство наслеђени од родитеља или предака (Ајдачић, 2016:52). Фразеологизми су настали метафоризацијом, а постулирана метафора гласи: БЛИСКОСТ ЈЕ ТЕЧНОСТ. Контрастивном анализом установљена је парцијална еквивалентност услед разлика на структурном и лексичком нивоу с тим што се поменуте разлике нису одразиле на семантичку симетрију.

Истом семантичком пољу припада и фразеологизам полазног језика å blande blod у значењу 'utføre ritual med å la hverandres blod renne sammen, i eldre tid som tegn på at man var fostbrødre, nå som tegn på at man er nære venner ${ }^{e}$ (ритуал у којем се крв две особе пусти заједно да тече, некада се тумачио као знак побратимства, а данас као знак блиског пријатељства) и реферише на бескрвно сродство. Исто значење у српском језику транспонује се путем фразема мешай крв и означава жељу да се са неким ородимо. На идентичну перцепцију блискосту упућује чињеница да је побратимство код Јужних Словена склапано посебним ритуалима, тако што побратими или посестриме пију или лижу једно другом крв или мешају своју крв (Мандић, 2016:17).

Обе фразеолошке јединице су мотивисане метафором БЛИСКОСТ ЈЕ НЕОДВОЈИВОСТ/НЕРАЗДВОЈИВОСТ с обзиром да се блискост концептуализује кроз течности које су неодвојиве (Сивачки, 2017:388). У полазном и циљном језику установљена је семантичка 
подударност, а контрастивном анализом је утврђена потпуна еквивалентност услед поклапања на лексичком и структурном плану.

\section{5 Негативна семантичка поља}

Као што је већ претходно назначено, концептуална анализа соматских фразеологизама са компонентом у значењу крв, у случајевима када је изражена маркираност у виду негативне емоције, карактеристике, стања или радње се врши у оквиру негативних семантичких поља која су у односу на изразе позитивне конотације знатно фреквентнија и у оквиру којих фигурира много већи број фразеологизама.

\section{Семантичко поље ЉУТЊА/БЕС/ГНЕВ}

Фразеолошка јединица у полазном језику blodet stiger noen til hodet/ansiktet/kinnene у значењу 'noen blir rød i ansiktet av anstrengelse, sinne, opphisselse e.1.' (неко је поцрвенео у лицу од напора, беса, узбуђења) денотира особу која је постала узнемирана, усплахирена, раздражљива, узрујана, љута, бесна и у циљном језику има свој фразеолошки еквивалент у фразеологизму јурнула је крв некоме у їлаву/ лище/образе. Фразеологизми су настали метафоризацијом при чему је емоција концептуализована постулирањем појмовне метафоре ЉУТЊА/БЕС/ГНЕВ ЈЕ ВРЕЛИНА. У српском језику, постоје и варијантни облици са глаголском лексичком варијаблом навире/наврла/ йојрила је крв некоме у ілаву/лище/образе при чему њихова употреба имплицира стилску маркираност. Контрастивном анализом је установљено да фразеологизми граде однос парцијалне еквиваленције услед неподударања на лексичком плану, с обзиром да су забележене глаголске и лексичке варијабле односно могућност измене лексичких компоненти, па се и на тај начин добијају синонимни фразеологизми. Незнатне лексичке разлике нису утицале на семантику фразеологизма у целини. На концептуалном плану је утврђена апсолутна еквиваленција као и идентична перцепција емоције у контрастираним језицима у чијој позадини је слика особе у стању беса, љутње или гнева са зајапуреним образима и црвенилом у лицу.

У оквиру истог семантичког поља са значењем побеснети спада и фразеолошки пар нор. blodet kommer i kok / срп. йрокључала/ 
ироврила/кийи крв некоме којима се реферише да је неко љут, бесан, раздражен, тј. разјарен. Контрастирањем је утврђено да фразеологизми успостављају однос парцијалне еквиваленције услед неподударања на лексичком плану. Код датих фразема забележена је потпуна еквиваленција у семантичком смислу, а у позадини је постулирана појмовна метафора ЉУТЬА/БЕС/ГНЕВ ЈЕ ТЕЧНОСТ при чему је емоција концептуализована као течност у посуди. Фразеологизми су настали метафоричким путем, при чему је соматизам концептуализован као посуда/садржатељ, а емоција као материја односно течност/ флуид у посуди према појмовној онтолошкој метафори ЉУТЊА/БЕС ЈЕ ФЛУИД/ТЕЧНОСТ.

\section{Семантичко поље МРЖњА}

Фразеолошка јединица у полазном језику å sette ondt blod hos у значењу 'vekke (varig) forbitrelse eller uvilje hos noen' (побудити огорченост, мржњу или неслогу код некога) денотира неслогу, раздор, нетрепељивост и фигурира у оквиру семантичког поља МРЖњА услед изражене маркираности у виду означавања негативне емоције. У циљном језику исто значење вербализује се путем фразеологизма

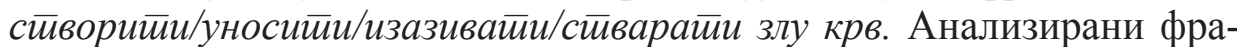
зеологизми настали су семантичком транспозицијом базне синтагме, односно мотивисани су семантичком доминантом крв, што значи да су настали мотивацијом симбола а не метафоризацијом (Ристић, 2013:120). За фразеологизме у српском језику, забележени су и варијантни облици, када неко изазива сукобе (на)правити злу крв, унети злу крв, створити злу крв, а у приликама када неко покушава да раније постојеће сукобе поново активира: подгревати злу крв, потпирити злу крв, оживети злу крв (Ајдачић, 2015:50). Услед лексичког неподударања констатован је однос парцијалне еквиваленције. На семантичком плану нема испољених разлика.

\section{Семантичко поље ХЛАДНОКРВНОСТ}

У оквиру семантичког поља ХЛАДНОКРВНОСТ, у полазном језику забележена је фразеолошка јединица med kaldt blod (rolig og med overlegg) у значењу бити присебан, миран, равнодушан односно 
хладнокрван. У циљном језику, идентично значење транспонује се

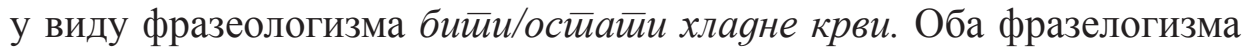
настала су метонимијским преносом с обзиром да је емоција коју денотирају концептуализована појмовним метафорама које почивају на метонимији: ХЛАДНОКРВНОСТ ЈЕ ХЛАДНОЋА/ХЛАДНА ТЕЧНОСТ И ХЛАДНОКРВНОСТ ЈЕ МИР. Сматра се да је метонимија честа у основи многих метафора (Klikovac, 2004:407-409). У српском језику је такође забележена семантички потпуно еквивалентна варијанта са лексичком варијаблом хлаgне іллаве, при чему може означавати и особу која се смирила након неког непријатног догађаја (Сивачки, 2017:377). Иако је контрастивном анализом утврђена парцијална еквиваленција на лексичком нивоу, није се одразила на семантички ниво, будући да фраземи почивају на заједничкој слици.

\section{Семантичко поље СТРАХ}

Емоција страха у норвешком и српском језику концептуализује се путем фразеологизама нор. blodet fryser til is / срп. крв се слеgила леgu/мрзне/некоме у жилама у значењу бојати се, осећати превелики страх, ужас и сл. Анализирани фразеологизми у оквиру овог поља настали су семантичком транспозицијом базне синтагме којом се означава физиолошко стање човека којем је хладно, а мотивисани су физиолошким осећањем језе и хладноће (Ристић, 2011:123). У позадини ових фразеологизама формулисана је појмовна метафора СТРАХ JE ХЛАДНОЋА и заједнички је изворни домен за фразеологизме контрастираних језика. Упркос универзалној перцепцији страха у изворном и циљном језику, степен еквивалентности је означен као парцијалан услед установљеног неподударања на лексичком нивоу у погледу допуне лексемом жиле у српском језику. На концептуалном плану нису уочене разлике, тако да је установљена идентична семантика.

\section{Семантичко поље СТИД}

Услед своје полисемичности, норвешки фразеологизам blodet stiger noen til hodet/ansiktet/kinnene са својим фразеолошким еквивалентом у српском језику йојрила је/јурнула/уgарила/наврла крв у ілаву/лице/образе некоме, фигурира у два семантичка поља, ЉУТњА/ 
БЕС/ГНЕВ односно у семантичком пољу СТИД. С обзиром да се емоција стида концептуализује на исти начин као и емоције љутње и беса, у основи ових фразема постулирана је метафора СТИД ЈЕ ФЛУИД/ТЕЧНОСТ. У свим наведеним примерима уочено је подударање на семантичком плану, што указује на идентичну перцепцију стида у норвешком и српском језику као и концептуализацију емоције постиђености, срамежљивости, непријатности.

Истом семантичком пољу припада и српски фразеологизам на-

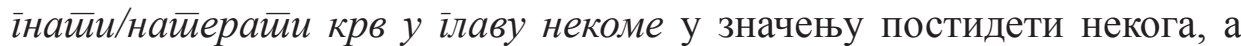
настао је метафоризацијом базне основе, односно почива на метафори СТИД ЈЕ ФЛУИД/ТЕЧНОСТ. У норвешком није забележен одговарајући фразеолошки еквивалент, већ се преношење значења српског фразема мора прилагодити помоћу нефразеолошког израза.

\section{Семантичко поље РАЗОЧАРЕЊЕ}

Норвешки фразеологизам slå/helle/tømme kaldt vann $i$ blodet y значењу 'dempe noens heftighet, begeistring, opphisselse' (пролити/ просути/испразнити хладну воду у крв некоме) означава особу која је доживела неко непријатно изненађење, шок или разочарење. Фразем је настао метафоризацијом, а мотивисан је сликом разочаране особе чије је одушевљење, усхићење или узбуђење спласнуло односно охладило се. Постулирана концептуална метафора у основи фразема је РАЗОЧАРЕЊЕ ЈЕ ТЕЧНОСТ КОЈА СЕ ХЛАДИ. У норвешком језИку фразем бележи неколико лексичких глаголских варијабли. За дати фразеологизам није утврђен одговарајући фразеолошки еквивалент у српском језику па је установљен однос нулте еквиваленције.

\section{Семантичко поље ТУГА/ПАТЊА}

Концепт патње у норвешком језику вербализује се помоћу фразема å gråte blod у значењу 'gråte sterkt' (плакати крв) и денотира особу која неутешно плаче услед бола или туге/очаја. Фразем је настао процесом метафоризације а емоција је концептуализована као течност у појмовној метафори ТУГА је ФЛУИД/ТЕЧНОСТ. Исто значење у српском језику транспонује се фраземом іорко йлакайи. Контрастивном анализом фразеолошког пара нор. å gråte blod/ срп. йлакайи їop- 
ко којим се изражава туга установљене су лексичке и структурне разлике, док је на семантичком плану утврђена подударност.

\section{Семантичко поље КРИВИЦА}

У оквиру овог семантичког поља фигурира фразеолошка јединица норвешког језика å ha blod på hendene y значену 'være (med)

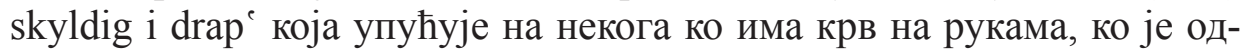
говоран за, или је саучесник у неком злоделу; злочинца или кривца за убиство. Злочиначка радња у српском језику вербализује се путем

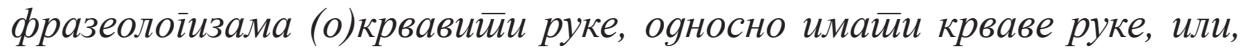

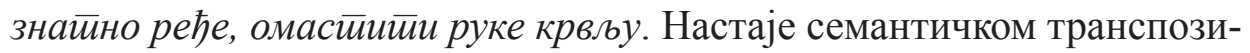
цијом базне синтагме којом се именује гест и вероватно је мотивисан „осећањем нелагодности због окрвављених руку услед нечијег убиства“ (Тривић према Мушовић 2015, 334). Уочене контрастивне разлике (на лексичком и структурном нивоу) нису се одразиле на когнитивном нивоу. Концептуалном анализом установљена је потпуна еквивалентност с обзиром да је у полазном и циљном језику у позадини слика човека који је пролио нечију крв и тиме се квалификује као злочинац или убица. Тиме је такође констатована и идентична перцепција кривице у контрастираним језицима.

Мотивацијом симбола, односно семантичком транспозицијом базне синтагме настао је и српски фразеологизам бийи у крви gо колена/ куйайи се у крви gо колена у значењу извршити крвопролиће, починити бројне злочине. Фразеологизам било је (биће) крви gо колена значи да је негде пало много жртава (Ајдачић, 2016:46). У норвешком језику забележен је фразем å ligge/svømme i (sitt) blod у значењу 'være voldsomt innsmurt i eget blod etter kamp, angrep, skade (лежати/купати се у крви након борбе, напада или повреде) и реферише на особу, која је повређена или убијена и дословно лежи у крви. Упркос установљеној парцијалној еквиваленцији на лексичком нивоу (у српском језику са додатном лексичком варијаблом колено). Анализирани фразеологизми илуструју случај привидне еквиваленције односно лажних пријатеља при чему је установљена семантичка асиметрија с обзиром да норвешки фразем не имплицира осећај кривице. 
Јована Д. Вурдеља

\section{3. Закључак}

Методом контрастивне анализе упоређени су соматски фраземи са компонентом blod/крв норвешког и српског језика, при чему је норвешки полазни, а српски циљни језик. Методом концептуалне анализе, односно утврђивањем начина мотивације, фразеологизми су сврстани у одговарајућа семантичка поља. Анализа је извршена на корпусу коју чини укупно 16 фразеолошких јединица норвешког језика и њихових одговарајућих еквивалената у српском језику.

На основу резултата истраживања, установљено је да соматизам blod/крв заузима важно место у фразеолошким системима норвешког и српског језика. Такође је потврђена и почетна хипотеза да соматизам $\mathrm{blod} /$ крв има врло развијену симболику и полисемију у контрастираним језицима, као и да га карактерише изразита фреквентност али и фраземотворна продуктивност. У раду је приказано да соматски

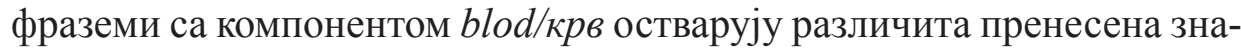
чења са позитивним и негативним конотацијама, а анализирани су на основу класификације у следећим семантичким пољима: љубав/ наклоност, блискост, љутња/бес/гнев, мржња, хладнокрвност, страх, стид, разочарење, туга/патња, кривица. Такође је установљен прилично уједначен број фразеолошких јединица у норвешком и српском језику имајући у виду семантички опсег лексеме blod и крв у поменутим језицима и чињенице да је утврђен исти број апстрактних значења. Међу анализираним фраземима, такође је примећено да је у контрастираним језицима израженији број фразеологизама којима се именују негативно маркиране емоције (укупно 10 фразема у семантичким пољима ЉУТЬА/БЕС/ГНЕВ, МРЖЬА, ХЛАДНОКРВНОСТ, СТРАХ, СТИД, РАЗОЧАРЕЮЕ, ТУГА/ПАТЬА, КРИВИЦА) У оДНОсу на оне којима се денотирају позитивне емоције (7 фразема у семантичком пољу ЉУБАВ/НАКЛОНОСТ, БЛИСКОСТ).

На основу спроведене анализе, са једне стране установљено је да соматски фраземи са компонентом blod/крв имају велики број заједничких карактеристика, односно да је утврђен висок степен подударности у погледу концептуализације и лексикализације ових фразема. Контрастивном анализом уочена су три типа еквиваленције; апсолутна еквиваленција, парцијална еквиваленција и нулта еквива- 
ленција За концептуализацију позитивних и негативних емоција, постулиране су следеће метафоре: ЉУБАВ ЈЕ ФЛУИД, ЉУТЬА/БЕС/ ГНЕВ СУ ВРЕЛИНА, ЉУТЬА/БЕС/ГНЕВ СУ ТЕЧНОСТ, СТРАХ ЈЕ ХЛАДНОЋА, СТИД ЈЕ ФЛУИД, РАЗОЧАРЕЊЕ ЈЕ ТЕЧНОСТ КОЈА СЕ ХЛАДИ, ТУГАА/ПАТЊА ЈЕ ФЛУИД/ТЕЧНОСТ. ДакЛе, установљена је универзалност појмовних метафора у неколицини примера, док су испољене разлике искључиво маргиналне, првенствено детерминисане различитим културолошким и физичким окружењем.

\section{ЛИТЕРАТУРА}

Ајдачић Д. (2016). Фразеолойизми са комйоненӣом 'крв' у срйскомјезику и књижевним gелима. Крв, књижевност, култура. Београд:Балканолошки институт САНУ. Посебна издања 134. стр.43-55

Милорадовић, С. (2016). Og рабойу се крвавеје, а оg школу луgеје. Крв, књижевност, култура. Београд:Балканолошки институт САНУ. Посебна издања 134. стр.11-17

Мандић М, Ђурић Љ. (2016). „Крвави” изрази и йсовкему савременом сриском језику. Крв, књижевност, култура. Београд:Балканолошки институт САНУ. Посебна издања 134. стр.17-43

Сивачки, А. (2017). Фразеолоіизми с консииииуенииом сомайской иорекла у албанском језикуи њихови иревоgни еквиваленйи у срӣском. Докторска дисертација.Филолошки факултет Универзитета у Београду.

Сивачки А, Мутавџић П. (2016) - Фразеолоіизми с констиииуентиом крв у иозитиивним семанииччким йољима у албанском језику и њихови ирревоgни еквивалениии у срисском. Прилоі конитрастиивној и формалносиирукииуралној и концейичуалној анализи. Крв, књижевност, култура (тематски зборник радова), Београд: Балканолошки институт САНУ, стр. 55-78

Тривић, А. (2015). Лексичко-семанииичка анализа сомаииизама у фразеоло-

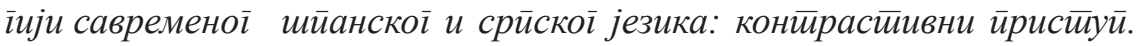
Докторска дисертација. Филолошко-уметнички факултет. Универзитет у Крагујевцу.

Штрбац, Г. (2017). Фразеолошки йоиенцијал сомайске лексике у срииском језику (на ирримеру сомайизама језик, ухо/уво, мозак и образ). Јужнословенски филолог LXXIII, св. 1-2 (2017) 
Ivanović Barišić, M. (2016). Pojmovnik srpske kulture. Etnološka obrada pojma „krv“. Beograd:Etnografski institut.

Klikovac D. (2004). Metafore u mišljenju i jeziku, Beograd: XX vek

Kövecses Z. (2010). Metaphor. A Practical Introduction, New York: Oxford University Press.

Lakoff, G. (1993). The contemporary theory of metaphor. Metaphor and Thought. Cambridge:Cambridge University Press, стр. 202-252

Lakoff G, Johnson M (2003). Metaphors We Live By. Chicago-London:The University of Chicago Press

Mršević-Radović, D. (1987). Frazeološke glagolsko-imeničke sintagme u savremenom srpskohrvatskom jeziku. Beograd: Filološki fakultet Beogradskog univerziteta

Mršević-Radović, D. (2008). Frazeologija i nacionalna kultura. Beograd: Društvo za srpski jezik i književnost Srbije.

Ristic, G. (2012). Liebe in Deutschen und Serbischen somatischen phraseologismen.. Annual Review of the Faculty of Philosophy, Novi Sad, Volume XXXVII (2012) Filozofski fakultet Univerziteta u Novom Sadu

Ristic, G. (2013). Somatizmi u nemačkoj i srpskoj frazeologiji (kontrastivna istraživanja). Doktorska disertacija. Filozofski fakultet Univerziteta u Novom Sadu.

Slovenska mitologija. Enciklopedijskirečnik.(2001).Zepter Book World:Beograd.

\section{Извори}

Bakker, B et.al. (1995). Norsk-serbisk/kroatisk ordbok. Oslo:Universitetsforlaget AS

Bokmålsordboka på nett. Доступно на: https://ordbok.uib.no/

Bokmålsordboka. Definisjons- od rettskrivningsordbok. Oslo:Universitetsforlaget AS.

Bergenholtz, Henning mfl. (1997): Nordisk leksikografisk ordbok. Oslo:Universitetsforlaget AS.

Det Norske Akademis Ordbok: Доступно на: https://naob.no/

Matešić, J. (1982). Frazeološki rječnik hrvatskoga ili srpskoga jezika. Zagreb: Školska knjiga

Otašević, Đ. (2007). Mali srpski frazeološki rečnik. Beograd:Alma.

Otašević, Đ. (2012). Frazeološki rečnik srpskog jezika. Novi Sad: Prometej 
Rečnik srpskog jezika. (2011). Novi Sad: Matica srpska

Rečnik srpskohrvatskog književnog jezika. Novi Sad:Matica srpska.

Store norske leksikon: Доступно на: https://snl.no/

\title{
Jovana D. Vurdelja
}

\section{SOMATIC PHRASEOLOGICAL UNITS IN NORWEGIAN AND SERBIAN WITH COMPONENT BLOD/KRV}

\begin{abstract}
Summary
The focus of this research is on the interlingual comparison of somatic phraseological units with component blod/krv in the Norwegian and Serbian phraseology from the cognitive perspective. Based on the contrastive and conceptual analysis, this paper aims to indicate similarities, differences as well as peculiarities, i.e., to determine the degree of semantic symmetry of the phraseological units in the given languages. By determining the mechanisms of motivation and classifying phraseological units in the corresponding positive and negative semantic fields depending on the emotion they denote, our research has shown three types of equivalence as well as exceptional polysemy and symbolic meaning of the lexeme blod/krv in the given languages.
\end{abstract} Serbian

Keywords: somatism, phraseological unit, blod, krv, Norwegian, 